IIPMOL 90095

\title{
Cloned GABA receptors are maintained in a stable cell line: allosteric and channel properties
}

\author{
Stephen J. Moss ${ }^{1,2}$, Trevor G. Smart ", Nada M. Porter "Naushaba Nayeem ", Joan Devine ${ }^{2}$, \\ F. Anne Stephenson ${ }^{3}$, Robert L. Macdonald ${ }^{4}$ and Eric A. Barnard ${ }^{\prime}$ \\ 'MRC Molecular Netwobiology Unit, MRC Centre, Hills Roud. Cambridge CB2 2QH, U.K..' British Biotechnology. Brook House. \\ Watlington Road, Cowley, Oxford OX3 SLY, U.K., "Deparment of Pharmatology, School of Pharmacy. London Litiversity. Briuswick

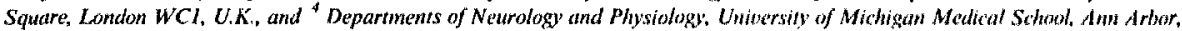 \\ MI 48104-10067, L'S.A.
}

Recuived 10 April 1990, accepted 25 April 1990

The cloned cDNAs encoding the $\alpha 1$ and $\beta 1$ subunits of the bovine brain $G A B A_{A}$ receptor have been co-transfected, using a dexamethasone-inducible promoter, into cultured hamster ovary cells, with selection to form a stable cell line. The use, alternatively, of a much stronger constitutive promoter led to cell death conscguent upon high receptor density. After induction, the cells contained the $\alpha 1$ and $\beta 1$ mP.NAs. The expressed receptors showed the high-affinity binding of $\left[{ }^{3} \mathrm{H}\right]$ muscimol and of the $\mathrm{GABA}_{\mathrm{A}}$ receptor channel blocker, t-butylphosphorothionate (TBPS), and the characteristic enhancement of the former by a pregnanolone. Their GABA-activated current was potentiated by the barbiturate, pentobarbitone, was reversibly blacked by bicuculline and picrotorin, but was not enhanced by benzodiazepines. In mouse spinal cord neurons GABA activates channel cpenings to at least four conductance states $(45,30,19$ and $12 \mathrm{pS}$ ) with the $30 \mathrm{pS}$ state being the most frequently observed (main) state. However, the main state of the $\alpha 1 / \beta 1$ GABA $_{\mathrm{A}}$ receptor was the $19 \mathrm{pS}$ state. The enhancement of GABA $\mathrm{A}_{\mathrm{A}}$ receptor current by barbiturates was due to prolongation of mean chanuel lifetime, whereas the reduction of $G A B A_{A}$ receptor current by picrotoxin was due to reduction of chamel opening irequency and mean channel lifetime. Stable cell lines containing subunit combinations of this receptor should provide a poweriul tool for the elucidation of its channel features and control mechanisms.

$\mathrm{GABA}_{\mathrm{A}}$ receptors; Expression; Cell lines (stable); Patch-clamping; Single channels

\section{Introduction}

GABA ( $\gamma$-aminobutyric acid) operates a gated Ci channel in the $\mathrm{GABA}_{\mathrm{A}}$ receptor of vertebrate brain, one of whose most interesting features is its allosteric regulation at a series of sites which recognize respectively benzodiazepines, barbiturates, certain steroids and convulsants such as TBPS

Correspondence to: Professor E.A. Barnard, MRC Molecular Neurobiology Unit, NiRC Centre, Mils Road, Cambridge CB2 2QH, U.X. (t-butylphosphorothionate; reviewed by Barnard, 1988). Further, this recepior has recently been established by DNA cloning apprnaches to exist in a number of subtypes (Levitan et al., 1988b). The minimum suburit structure appears to contain $\alpha$ and $\beta$ types of suburit (which themselves exist in multiple subtypes, e.g. $\alpha 1, \alpha 2$, etc.) in a form of the receptor that is essentially insensitive to benzodiazepines (Blair et al., 1988; Levitan et al, 1988a), whreas a third type of subunit $(\gamma)$ can be present in the more usual benzodiazepine-sensitive forms (Pritchett et al., 1999). Transient expression has been achieved of $(\alpha+\beta)$ subunits in 
the Xinopur oosyco (soholield at al, 1087: Levitan of al, 1988, b), and of $(\alpha+\beta)$ or $(\alpha+\beta+\gamma)$ subunits in oulured mammalian cells (Pritchet at al. $1988 ; 1989$ ). We have now obuaned inducible, stable expression of $(\alpha+\beta)$ subunits in a mammalian cell line, and show that these form a stable receptor/channel. The results demonstrate also that the native type of bicuculline, barbiturate, TBPS and steroid allosteric regulatory systems are present within the $\alpha$ and $\beta$ subunits.

\section{Matorials and methols}

\subsection{Plasmid construction and cell trans/ection}

The $\alpha 1$ and $\beta 1$ cDNAs encoding the bovine GABA $A_{A}$ reteptor $\alpha 1$ and $\beta 1$ subunits (Schofield et al., 1987) were cloned (using synthetic Nhel linkers) into the polylinker of a plasmid containing the mouse mammary tumour virus (MMTV) promoter, plus an ampicillin-resistance marker and a poly-adenylation acceptor sequence. Each was orientated by restriction analysis, to yield plasmids MMTV-at and MMTV- $\beta 1$. The $\alpha 1$ and $\beta 1$ cDNAs were also cloned into the polylinker of plasmid p-Bex 4 (British Biotechnology, Ltd.) which is similar but contains the human CMV promoter to yicld plasmids HCMV-al and $H C M V-\beta 1$. Selection of stable cell lines with either vector is due to the presence, also, of a gpt resiom tance cassette.

into the same plasmids (without GABA receptor cDNA inserts) the chloramphenicol transferase (CAl) gene was inserted using an identical method, is yield the plasmids MMTV-CAT and HCMV.CAT. CAT activity was assayed after expression as described by Gorman (1985).

Cultured hamster ovary (CHO) cells were maintained in Dulbecco's modified Eagle medium (DMEVi) suppiemented with $5 \%$ ieal cail serum, $2 \mathrm{mM}$ glutamine, $100 \mathrm{w} / \mathrm{ml}$ penicillin- $\mathrm{C}$ and straptomycin at $37^{\circ} \mathrm{C}$ in $5 \% \mathrm{CO}_{2}$. For transfecticn, exponentially growing cells were trypsinized, seeded at $5 \times 10^{5}$ cells per $9 \mathrm{~cm}$ dist and in. cubated overnight in $10 \mathrm{ml}$ growth medium. Cells were then transfected using the calcium phosphate/BES method as described by Chen and
Oknyuma (1987). Linearized $\alpha 1$ and $\beta 1$ cDNAs were mixed in a $1: 1$ ratio; $5 \mu \mathrm{g}$ DNA was used per dish. Then $48 \mathrm{~h}$ after transfection, the cells wore trypsinized and seeded at $1 \times 10^{5}$ cells per dish. For selection, the growth medium was supplemented with xanthine $(0.25 \mathrm{mg} / \mathrm{ml})$, mycophenolic acid $(5 \mu \mathrm{g} / \mathrm{ml})$ and $1 \times \mathrm{HT}$ supplement. All medium constituents were from Gibco. Resistant colonies were evident 5-10 days after selection; individual colonies were ssolated and grown up in selective growth media.

For RNase A protection analysis two further conchucts were produced: a 527 bp EcoRI Scal fragment, encoding the first 527 bp of the GABA wl subunit (Schofield et al., 1987), was cloned into the polylinker of plasmid p-Gem 4 (Promega Biotec) to yield p-4al, and a 300 bp Kpnl Eco RI fragment encoding nucleotides 403-703 of the $\beta$ ! subunit was cloned into the polylinker of $\mathrm{p}-\mathrm{Gem}$ $4 Z$ io yield plasmid $p-4 Z \beta 1$. Plasmid DNA was prepared by Triton $\mathrm{X}-100$ lysis followed by $\mathrm{CsCl}$ fractionatiol, as descrihed by Maniatis et al. (1982). Prior to transfection the MMTV- $\alpha 1$ and MMTV $\beta 1$ vectors were linearized by digestion with Norl.

\subsection{Introduction and isolation of total PNA}

Resistant cells were expanded from stocks - naintined : 7 liquid nitrogen in $T 75$ tissue culture flasks to hali confluence. Dexanethasone was added to a final conventration of $2 \mu \mathrm{M}$ to induce transcription of the MMTV promoter. At $48 \mathrm{~h}$ after induction the cells were washed with DMEM before prepasation of total RNA using guanidinium isothiocyanate (Chirgwin et al., 1979).

\subsection{RNase protection analysis}

${ }^{32}$ p.tabelled RNA anticense jrobss were proculucer in vitro trinscription of EcoRI lincarizad p4IZal (utilising the $T 7$ promoter) and of Kpnl linearized plasmid $\mathrm{p} 4 \beta 1$ (as described by Treisman (1987)). RNA probes were purified by denaturing gel electrophoresis (Maniatis et al., 1982). The relevant ianiolabelled probe $\left(5 \times 10^{5}\right.$ cpm) was then hybrdized with $50 \mu \mathrm{g}$ total RNA from resistant colonies transfected with the al and 
BI GABA receptor cDNAs, or total RNA from untransfected control $\mathrm{CHO}$ cells, overnight at $45^{\circ} \mathrm{C}$ in $80 \%$ formamide/ $100 \mathrm{mM} \mathrm{NaCl} / 80 \mathrm{mM}$ PIPES (pH 6.4) $/ 5$ mM EDTA. The reaction mixtures were then treated with RNase A $(40 \mu \mathrm{g} / \mathrm{ml})$ and $R$ Nase $T 1(0.5 \mu \mathrm{g} / \mathrm{ml})$ in the total volume of $350 \mu$ l of $100 \mathrm{mM}$ EDTA/ $20 \mathrm{mM}$ Tris $-\mathrm{HC} 1 \mathrm{pH}$ 7.5). Protected fragments were phenol-extracted. ethanol-precipitated, and separated on denaturing gels (Maniatis et a!., 1982). The gels wore then exposed to Fuji X-ray film at $-70^{\circ} \mathrm{C}$ using an intensifying screen.

\subsection{Southern blots}

Genomic DNA was isolated from confluent flask cultures of resistant clones, as described by Maniatis et al. (1982). A $10 \mu \mathrm{g}$ sample of DNA was digested with $X b a \mathrm{I}$, and Southern-blotted from $1 \%$ agarose gel onto nitrocellulose. Blots were hybridized with a randomly labelled (Feinberg and Vogelstein, 1983) cDNA (1.8 kb) encoding the entire $\beta 1$ subunit of the GABA $\mathrm{A}_{\mathrm{A}}$ receptor. Hybridisation was in $50 \%$ formanice $5 \times \mathrm{SSC}(1$ $\times \mathrm{SSC}=0.15 \mathrm{mM} \mathrm{NaCl}, 15 \mathrm{mM}$ trisodium citrate), $0.5 \%$ SDS, $0.1 \%$ polyvinylpyrrolidine, $0.1 \%$ Ficoll $400,0.1 \%$ bovine serum albumin, $250 \mu \mathrm{g} / \mathrm{ml}$ sonicated salmon sperm at $42^{\circ} \mathrm{C}$ for $2 \mathrm{~h}$, before the addition of radiolabelled $\beta 1$ subunit probe at $10^{6} \mathrm{cpin} / \mathrm{ml}$. The blot was finally washod in $0.1 \times$ SSC at $65 \%$ for $1 \mathrm{~h}$.

\subsection{Immtmo-blots}

Crude membranes were prepared from confluent flask-cultures of resistant clones induced for $48 \mathrm{~h}$ with dexamethasone prior to harvesting. The cells were homogenized in $4 \%$ Triton $\mathrm{X}-100 / 100$ $\mathrm{nM} \mathrm{MgCl}_{2} / 10 \mathrm{mM}$ Tris-HCl (pH 7.5) in the presence of $10 \mathrm{mM}$ EDTA and EGTA. Crude bovine brain nembranes and pure bovine $\mathrm{GABA}_{\mathrm{A}}$ receptor (Sigel and Barnard, 1984) served as positive controls, while crude membranes prepared from untransfected $\mathrm{CHO}$ cells served as further controls. Extraction into sodium dodecvl sulfate (SDS) sample buffer, precipitation by trichloroacetic acid, SDS gel electrophoresis and Western blotting wer: all performed as described by Casa- lotti et al. (1986), using a monoclonal antibody, 1A6, to the GABA A receptur $\alpha$ subunit, described by Mamalaki et al. (1987).

\subsection{Cell culture}

Spinal cords were dissected from 12-14 day old murine fetuses and grown in cell culture as described previously (Macdonald et al., 1989a). Cultures were maintained for $2-5$ weeks prior to being used in these experiments.

\subsection{Electrophysiology; whole cell recording}

Experiments were perforrned using the wholscell recorcing technique with a List EPC7 patch clamp amplifier. SCG (superior cervical ganglion) neurones were obtained from E21 rats and grown in culture as previously described (Smart, 1987). The CHO cells and SCG neurones were continuously superfused in the culture dish at $28^{\circ} \mathrm{C}$ with a HEPES-Krebs solution of the composition $(\mathrm{mM}) ; \mathrm{NaCl} 140, \mathrm{KCl} 4.7, \mathrm{MgCl}_{2} 1.2, \mathrm{CaCl}_{2} 2.5$, glucose 11, HEPES 5 , buffored to $\mathrm{pH} 7.4$. Electrodes were fabricated from borosilicate glass and heat-polished to a final diameter of $0.5-1.5 \mu \mathrm{m}$. The recording pipette soiution contained either (mVi) $\mathrm{KCl} 30$, KAsp $120, \mathrm{MgCl}_{2}$ 1, EGTA 0.5, $\mathrm{CaCl}_{2} 0.28$, HLPES 5, buffered to $\mathrm{pH} 7.0$ with 1 M NaOHi (final concentration $3 \mathrm{mM}$ ); or $\mathbf{K C l}$ $150, \mathrm{MgCl}_{2}$, EGTA $0.5, \mathrm{CaCl}_{2} 0.28$, HEPES 5 , bulfered to , 7.4 with $1 \mathrm{M} \mathrm{NaOH}$. Data were recorded on a Brush-Gould ink-jet pen recorder. GABA was either bath-applied or applied from an adjacent patch pipette filled with $50-500 \mu \mathrm{M}$ GABA and ejested ising $N_{2}$ pressure. Healthy CHO cells had resting potentrais varying fron 32 to $-58 \mathrm{mV}$ with a linear $1 / \mathrm{V}$ relation thip, while SCG neurones had resting tentials of -48 to $-72 \mathrm{mV}$ and spike amplitudes of $>100 \mathrm{mV}$.

\subsection{Electrophysiology: single channel recording}

The medium used to grow and maintain the cultures was exchanged for an extracellular salt solution which consisted of the following, in $\mathrm{mM}$ : $142 \mathrm{NaCl}, 8.1 \mathrm{KCl}, 1 \mathrm{CaCl}_{2}, 6 \mathrm{MgCl}_{2}, 10$ glucose, $10 \mathrm{Na}$-HEPES (pH 7.4). The intrapipete solution 
continod, th m: $153 \mathrm{KCl}, 1 \mathrm{MgCl}, 10 \mathrm{~K}$. HLPES, 5 DTA (pH 7.38). This combination of extracellular and intrapipete solutions resulted in a chloride equilibrium potential $\left(E_{C l}\right)$ of about 0 $m V$ and a potassium equilibrium potential $\left(E_{K}\right)$ of $-75 \mathrm{mV}$ across the patch menorane. All experiments were performed at room temperature (20$23^{\circ} \mathrm{C}$ ).

GABA was difuted with extrs sellular solution from a $10 \mathrm{mM}$ stock solution to a final concentration of $5 \mu \mathrm{M}$ on the day of the experiment. All drugs were obtained from Sigma Chemical Co., (St Lotis, MO, U.S.A.). OABA or GABA with a drug was applied to the patch membrane using

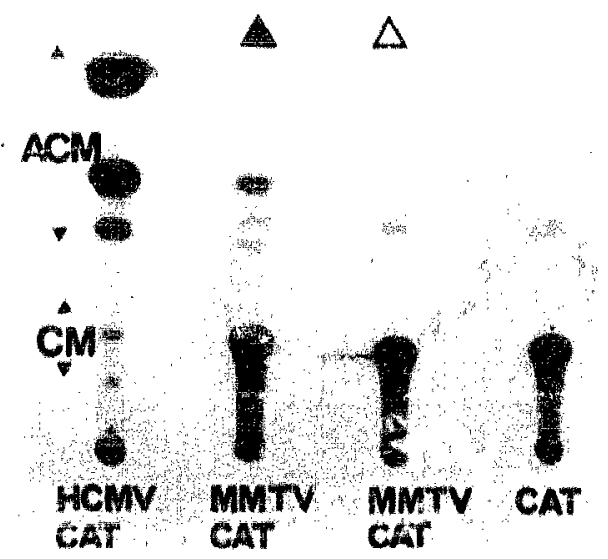

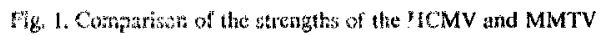
prometers in $\mathrm{CHO}$ cells. $\mathrm{CHO}$ cells were transfected with the incitcated plasmids (see Materiais and methods). Cit was derived from HCMV.CAT by deletion of the HCMV promoter. Cells were re-supplied $24 \mathrm{~h}$ aiter transfection with either nomal growth medium (HCMV-CAT and CAT), or medium supplenented with $10^{-6} \mathrm{M}$ dsxamethasone (A). or medium supplemented only with ethanol (dexamethasone solvent) to $0.05 \%(\alpha)$. Cells wera harvested 48 h later ${ }^{2}$ lysed by ropeated sycles of freezing and thawing, and the induced CAT activity was atsayed. ACM, acylated chloramphenicol; CM, chlo* ramphenicol. Quantitation showed that the percentage conversion to all products was 100 times greater for HCMV than for MMTV (inducki), and M MTV was a further five- to 10-fold weaker when not inducud. pressure giection micropipettes which were moved to within $50 \mu \mathrm{m}$ of patches only during the time of drug application.

Recording techniques were similar to those previously described (Hamill et al., 1981; Macdonald et al., 1989). Excised outside-out patches were obtaine using a List model L/M EPC-7 patch clamp amplifier and were simultaneously recorded on a video cassette recording system (VCR) (SONY SL-2700) via a digital audio processor (SONY PCM-501 ES, modified to 0-20 kH: 14-bit resolution, $44 \mathrm{kH} \%$ sampling (requency) and a Brush-Gould ink-jot pen recorder. At a later time, the data were played back from the VCR and digitized $(20 \mathrm{kHz}, 14 \mathrm{bit})$ with a $2 \mathrm{kHz}(3 \mathrm{~dB})$ 8-pole Bessel filtci interposed. Current amplitudes and durations were determined by computer using softwar previously described (Macdonald et al., 1989). Openings and closings were detected using the $50 \%$ threshold crossing method and were acc.jpted as valid events if their durations were greasier than twice the system dead time (dead tims $=70 \mu \mathrm{s}$ ). Measured open times will generally be longer than 'true' open times due to undetected openings. Throughout the text the term 'apparent open time" will refer to measured the time that has not been corrected for unobserved transitions (M.Manus et al, 1987).

\section{3. iktosuits}

\subsection{Transfection and comparison of expression with two vector types}

Chio wells were transfected with plasmids containing (separately) the al and $\beta 1$ subunit cDNAs of the bovine GABA receptor. These were uivent either by a human cytomegalovirus promoter (HCMV) ni y a mouse mammary tumour virus promoter (MMTV), both with selection isy gpt resistunce. It was found that the MMTV ( $\alpha 1+$ $\beta 1$-transfected cells could be selected through many passages with good yield throughout, whereas the HCMV $(\alpha 1+\beta 1)$-transfected cells died out in the first growh sycle after transfection (table 1). The latter behavior was autributable to the presence of the $G A B A_{A}$ receptor in this 
TABLE I

Comparative yields of ept-resstant CHO colonies after trans. fection. Exponentially growing cells $\left(5 \times 10^{5}\right)$ were co-transfected with the pairs of plasmids shown, or with HCMV-CAT alone, which contains a chloramphenicol acetyltransferase gene in place of a GABA receptor subunit cDNA. After transfection the number of resistant colonies was determined after 7 days in the selection medium.

\begin{tabular}{ll}
\hline Ptasmids & $\begin{array}{l}\text { Number of resistant } \\
\text { colonics por } 10^{\circ} \text { cells }\end{array}$ \\
\hline MM'TV-al +MMTV $\beta$ & $>10^{1}$ \\
HCMV- $\beta 1+H C M V-\beta$ & -1 \\
HCMV-CAT & $>10^{3}$ \\
\hline
\end{tabular}

H.CMV-driven expression, since when the receptor was replaced by the CAT gene the toxicity disappeared, and the same was true when other non-re- ceptor DNAS were expressed therein. Further, the HCMV-transfected cells with $\alpha 1+\beta 1$, containing only $\mathrm{CAT}$ as the exogenous gene, constantly expressed a high level of CAT activity (fig. 1). Likewise. use of the SV40-early promoter led to the same unstable effect as the HCMV promoter (data not shown). In contrast, the constant growth of the MMTV-CAT-tansfected cells was accompanied by little expression of CAT: this could be increased five- to 10 -fold by the induction with dexamethasone.

\subsection{Characterisation of the ghtowistant dones}

The cells co-iansfected with MMTV-al and MMTV- $\beta 1$ and then gpt-selected were shown to

\section{$\begin{array}{llllllll}1 & 2 & 3 & 4 & 5 & 6 & 7 & 8\end{array}$}
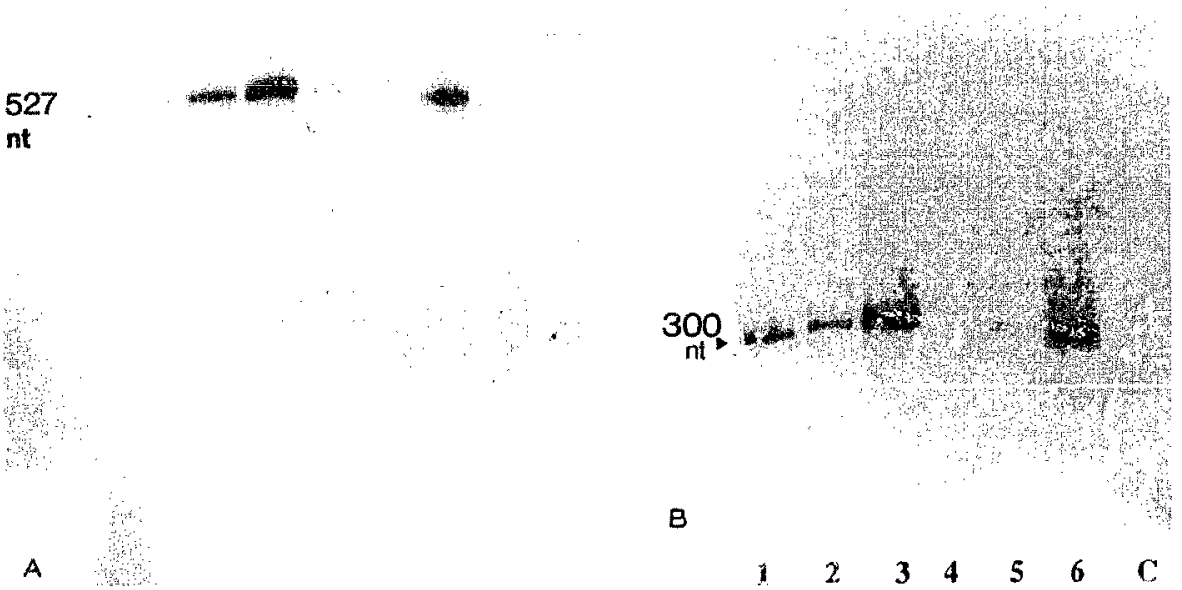

Fif. 2. RNase A protection analysis. Total RNA was harvested from 6 serarate cell kines transfected with both the $\alpha$ and $\beta$ ! subunits of the GABA receptor subunits under the control of the inducibie NMTV prom ster, and from control CHO $\mathrm{cf} l \mathrm{lls}$. The RNA was then hybridized with the al subunit antisense probe (A) or with the $B I$ subunit antusense probe (B). RNast-resistant fragments were seprated on a $6 \%$ acrylamide $7 \mathrm{M}$ urea gel (Zinn et al., 1983). Lanes 1-5 (A and 1): RNA from different well lires; dane 7 (A) and $C$ (B) control (untransfected) cells. Undigested probe was also included in A (lante 8). End-habelled fragments of a Mspl digest of pllR322 served as saze markers (not shown). Gols were expost to Fuil tilo at $-70^{\circ} \mathrm{C}$ for 7 days. The same range of intensity vt expression as seen here was found in other cell hines in which al and $\beta 1$ alone had been stably infroduced, when the resjective probes were uted alone (not illustrated). 


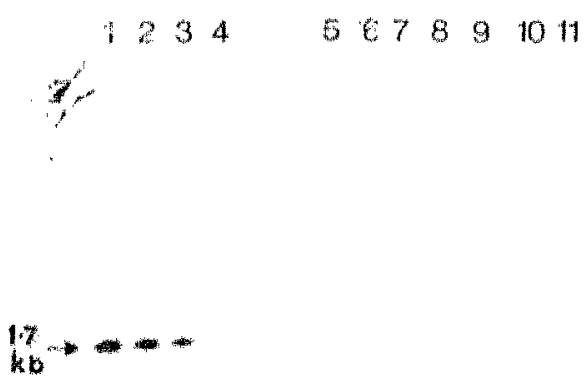

Jig. 3. Southern bin of DNA isolated from $(\alpha+\beta 1)$ cell hines, liybridized with o $/ \beta$ subunt probe. $10 \mu$ g of genomic DNA from 6 sel: lines contransiected with the CABA receptor al

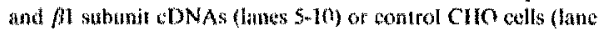
11) af (lanes 1.4) 48,36,24 and $12 \mathrm{pg}$ of plasmid MMTV- $\beta$ were digested with $N$ he', electrophoresed on a 18 agarose gel and Southern bloted. The probe used was the entire $\beta 1$ subunit CONA. Exposure was to Fuji film at $-70^{\circ} \mathrm{C}$ using an intensifying screen for $24 \mathrm{i}$. In the marker lane (extreme left) a $1.6 \times k$ marker band is visible.

have stably integrated the $\alpha$ and the $\beta 1$ subunit CDNAs. This is shown by Sotwhen bloting in fig. 2 for the $\beta 1$ cDNA, will standart quantities of the insert alone for comparison. The results show that from one to five copies have been integrated per cell. Identical rusults were obtained with the di insert in the same cells (data not shown).

The subunit transeripts produced in these cells (alter induction for $48 \mathrm{~h}$ ) werc recognired by RNase protection with the corresponding probes (fig. 3). This showed that all of the cell lines produce $\dot{f}$ conain the $\alpha 1$ and $\beta 1 \mathrm{mRNAs}$ together. The amounts varied considerably and at random between the cell lines, depending upon the nosition of genomic integration of the foreign DNA. However, the of and $\beta$ INAs always were comcorporated to the stme orde; of nutgitude, wine the same ange $\alpha^{\prime \prime}$ incouprition between stable lines was shoun when $\alpha+$ or $R 1$ were transfected alone (not shown). Since the wl and $\beta 1$ probes were equally labelled and theif sizes were fairly similar, the results showed that cell lines 3 and 6 had the highest levels of hoth $\alpha$ l and $\beta 1$ mRNA and these were chosen for iong-term use.

\subsection{Reactions with anti-GAEA receptor monoclonal antibody}

The production of subunit polypeptide was monitored by immunoblo'ing. This was only possible for the al subunit, since no antibody specific for the $\beta$ l subunit has yet been obtained.

Using a monodonal antibody, 1A6, directed against $\alpha$ subunits (Mamalaki et al., 1987). it was shown (fig. 4) that the $\alpha 1$ polypeptide was recognized and was present in $(\alpha 1+\beta 1)$ and in $\alpha 1$-alone transfected calls. The $\beta 1$ subunit was not recognized, either in $\left(\alpha^{2}+\beta 1\right)$ or in $\beta 1$-alone transfected cells. As noted previously (Mamalaki tt al., 1987), a band in the $\beta$ region was recognized by $1 \mathrm{~A} 6$ in the receptor from native brain membranes

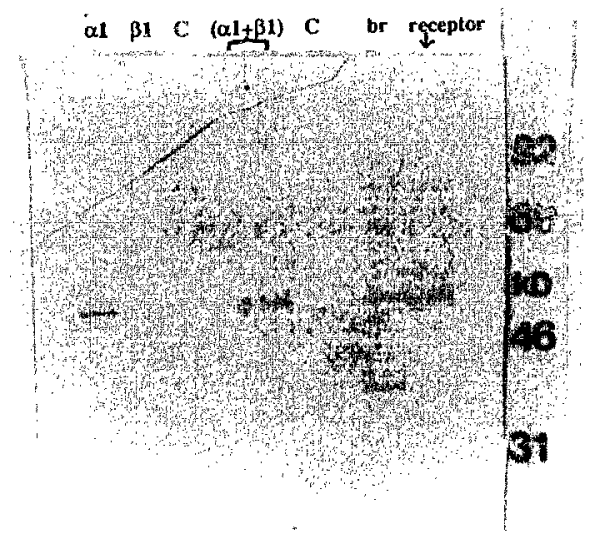

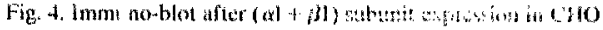
cells. Samples (ton $\mu \mathrm{g}$ protein) from dells lromstectes with

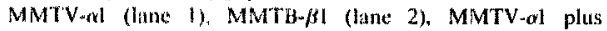
AMTis- $\beta 1$ (lanes 4 and 5 ) were electrophoresed and immunobloted (sec Materials and methods). Also included in the blot were crude bovine brain membranes (br; $150 \mu \mathrm{g}$ of protein), purified $\mathrm{GABA}_{\mathrm{A}}$ receptor protein ( $100 \mathrm{ng}$; arr $\mathrm{W}$ ) and membranes from untransfectud cells (control, $C$ ). The positions of

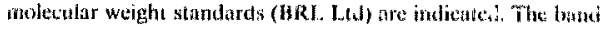

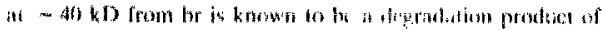

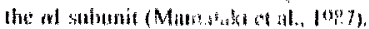


TABLE: 2

Binding sites in cel membranes transfeeted with $(\alpha l+\beta 1)$ subunits. Ligands (Amersham) were at $25.3 \mathrm{Ci} \mathrm{mmol}^{-1}$ for muscimol or $87 \mathrm{Ci} \mathrm{mmol}^{-1}$ for TEPS, each at $40 \mathrm{nM}$ or satur.ting concentration. Nonspecific binding was measured in the presence of $1 \mathrm{mM} \mathrm{GABA}$ (muscimol), $10 \mu \mathrm{M}$ picrotoxin (TBPS) or $3 \mu \mathrm{M}$ clonazepam (flunitrazepam). Membranes prepared from cells and assayed as in Casaloti et al. (1986). Values are means $\pm S$.E. of triplicates in three independent determinations.

\begin{tabular}{|c|c|c|c|}
\hline Ligand & $\begin{array}{l}\text { fmol/tung } \\
\text { protein }\end{array}$ & $\begin{array}{l}\text { Imol } / 10^{\circ} \\
\text { cells }\end{array}$ & $\begin{array}{l}\text { Binding } \\
\text { sites/cull }\end{array}$ \\
\hline$\left[{ }^{3} \mathrm{H}\right]$ Muscimol & $15.6 \pm 3.7$ & 0.26 & 156 \\
\hline${ }^{33}$ 3TRBPS & $13.7 \pm 2.0$ & 0.23 & 138 \\
\hline$\left[{ }^{3} \mathrm{H}\right] \mathrm{Flunitrazepam}$ & Nont & None & None \\
\hline
\end{tabular}

(fig. 4), but it could be seen that this is not the $\beta 1$ subunit and could be attributed to the $\alpha 3$ subunit. present in the receptor purified from bovine cortex and migrating in tha $\beta 1$ region (Stephenson it al., 1989).

\subsection{Ligand binding of the expressed receptors}

The membranes of the $(\alpha 1+\beta 1)$ transfected, dexamethasone-induced cells bound $\left[{ }^{3} \mathrm{H}\right]$ muscimol and $\left[{ }^{35}\right.$ SJTBPS in the nanomolar range (table 2 ). The amounts were low, corresponding to only 100-300 binding sites per cell, but these levels were reproducible and significant.

The $\mathrm{GABA}_{\mathrm{A}}$ receptor in native neurones is sensitive to certain steroids of the prognanolwe/ alphaxolone/corticosterone series r? pters et al.. 1988), and this can be monitured by their enhancement of the binding of GABA or muscimel (Harrison and Simmonds, 1984). This effect was present, to the same degree, when the $(\alpha 1+\beta 1)$

TABLE 3

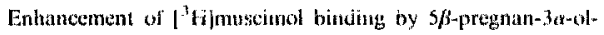
20 -one $(100 \mu \mathrm{M})$ in cell mombranes.

\begin{tabular}{|c|c|}
\hline Sample & $\begin{array}{l}{\left[{ }^{3} \mathrm{H}\right] \mathrm{muscimol}(40 \mathrm{nM})} \\
\text { binding (\% of con trol) }\end{array}$ \\
\hline 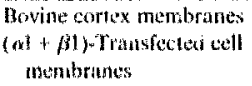 & $\begin{array}{l}170 \% \\
160 \%\end{array}$ \\
\hline $\begin{array}{l}\text { Untrandected coll } \\
\text { membraties }\end{array}$ & Nonc \\
\hline
\end{tabular}
A sce
8 CHO

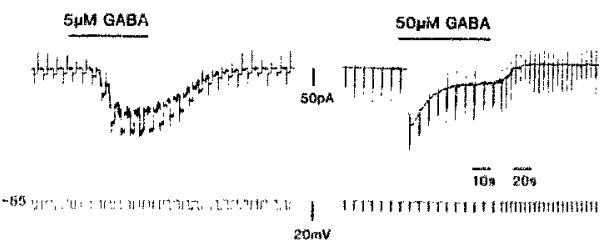

Fig. 5. Rusponse w GABA of $(\alpha \mathrm{a}+\beta \mathrm{i})$-transfected CHO celis and of SCG neurones. (A) A sympathetic neurone was wholecell voltageclamped at $-55 \mathrm{mV}$ and subjected to $10 \mathrm{mV}$. hyperpolarizing commands for 500 ms every $5 \mathrm{~s}$. Bath applicalion of $5 \mu \mathrm{M}$ GAMA evoked an inward surrent coupled with at dear increase in membrane ronductance atnd metriblane cur-

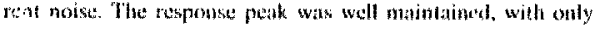
slight fading during application of the agonist. Note that the chart rocorder speed was internittently increased during each voltage command. (B) GASA responses were recorded from C. 10 cells at $-55 \mathrm{mV}$ (tayperpolarizing voltage steps of 10 $\mathrm{mV}$, for $500 \mathrm{~ms}$ ) following bath application of $50 \mu \mathrm{M} \mathrm{GABA}$. which was diosen to produce a 'matched-current' response compared to ( $A_{1}$ ). The CHO-cell response profile differed from that observtd in cultured SCG neurones by fading quite rapidly during exposure to GABA, which may be representative of a more ovtr1 desensitization process in the expressed GABA receptors residing in the $\mathrm{CHO}$ cells. In addition. the conductance increase was considerably smaller in the latter with virtually no discernable metubrant cerrent noise. Note the difference in the concentrations of CABA required for $\mathrm{CHO}$ and SCG cells to produce matched GABA responses.

transtected cells were testrod whit one of the steronds involved (table 3).

\subsection{Expressed receptor channels}

\subsubsection{Occurrence and density of receptors}

After the dexamethasone-induction of MMTV. $(\alpha 1+\beta 1)$ transfected cells, a maximal response to applied GABA could be detected within $48 \mathrm{~h}$ upon recording the evoked inward currents (fig. 5). The level of response seen was not changed after numerous passages of the positive cells, so that this cell line was stable. In contrast, the HCMV-(a) $\beta 1)$ transfected cells initially gave greater currents, but these were very variable beIween cells and all disappeared after the first growth cycle.

With the MMTV- $\left(\alpha 1+\beta^{x}\right)$ translected cells after induction, the density of receptors, as esti- 
mated by the size of the GABA-evoked membrane currents, varied considerably arcund the mean illustrated in fig. 5. Bath application of $50 \mu \mathrm{M}$ GABA produced a mean inward current of 81 $\mathrm{pA} \pm 14.5 \mathrm{pA}$ (standard error from 12 cells obtained from two batches of CHO cells separately induced by dexamethasone). Generally, bath concentrations of GABA required to activate these receptors were about 10 times those required to activate the $\mathrm{GABA}_{\mathrm{A}}$ receptors on dissociated mammalian neurones (fig. 5). The relative receptor densities were also apparent when puffing GABA over the $\mathrm{CHO}$ cells, which resulted in a small response with a slow onst, despite the pipetie being closer than cile cell diameter away from the recording site. The peak current obtained from CHO cells (at $-55 \mathrm{mV}$ ) with GABA applied with $88 \mathrm{k} \mathrm{Pa}$ pressure was again about 10 -fold lower than that obtained from SCC neurones witl: GABA applied similarly (at $70 \mathrm{kPa}$ ) (data not shown).

\subsubsection{Reversal potential and phamacology}

The reversal potential for the GABA response followed the $\mathrm{Cl}^{-}$reversal potential closely. For examole, when using the aspartate/low $\mathrm{Cl}^{-}$ medium in the pipette (see Materials and methods) $\mathrm{E}_{\mathrm{GABA}}$ was $-38 \mathrm{mV}\left(\mathrm{E}_{\mathrm{Cl}}=-40 \mathrm{mV}\right)$, and when using the $\mathrm{Cl}^{-}$-based medium. $\mathrm{E}_{\mathrm{GABA}}$ was -4 $\mathrm{mV}\left(\mathrm{E}_{\mathrm{Cl}}=0 \mathrm{mV}\right)$.
A

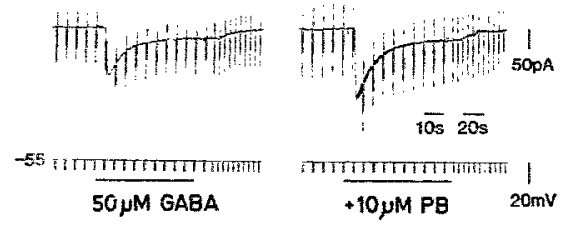

Fig. 6. GABA responses were entanced by pentobarbitone. The $(a 1+\beta 1)$-transfected cells were whole-cell voltage-clamped at $-55 \mathrm{mV}$ following expression of $\mathrm{GABA}_{\mathrm{A}}$ receptors, and subjected to $10 \mathrm{mV}$ hyperpolarizing voltage command steps (lower trace). (A) Bath application of $50 \mu \mathrm{M}$ GABA produced an inward current (top trace) and a conductance increase which ripidly faded on continued exposure to the agonist. (B) In the presence of $10 \mu \mathrm{M}$ pentobarbitone ( $\mathrm{PB}$ ). the peak GABA response was clearly enhanced, together with the membrane current noise. This effect of $\mathrm{PB}$ was readily reversible on washing.
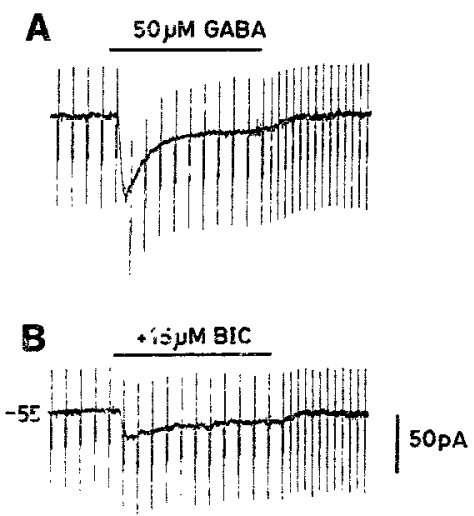

$$
\overline{10 s} \overline{20 s}
$$

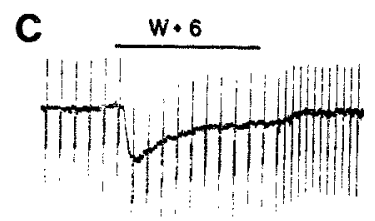

Fig. 7. GABA A $_{\text {ing }}$ receptors expressed on $(\alpha 1+\beta 1)$-transfected C:10 cells were sensitive to blockade by bicuculline. (A) Control invard GABA currents were routinely produced under whole-cell voltage clamp by the bath application of GABA (ju-200 $4 \mathrm{M}$ ) - (B) The presence of $15 \mu \mathrm{M}$ bicuculline for $3 \mathrm{~min}$ strongly inhibited the GABA response. (C) Reversal of the bicuculline blockade readily occurred on washing for $6 \mathrm{~min}$.

Enhancement by pentobarbitone (10-50 $\mu \mathrm{M}$; $n=4$ cells) was seen with increases in the range of 50-110\% (fig. 6). Bicuculline methobromide also inhibited the GABA response but was less potent than with the SCG neurones (fig. 7). At least 15 $\mu \mathrm{M}$ bicuculline was required to produce a reasonable block of the GABA response; in comparison, concentrations $<10 \mu \mathrm{M}$ were sufficient to completely abolich the neuronal GABA response on cultured sympathetic neurones. Lastly, when GABA was applied at $10-100 \mu \mathrm{M}$, there was no enhancement detectable by the benzodiazepines, flurazepam $(5-10 \mu \mathrm{M})$ or chlorazepate $(5-10 \mu \mathrm{M})$ ( $n=8$ cells each). 
Spinal Cord Neurone

a) $5 \mu M G A B A$

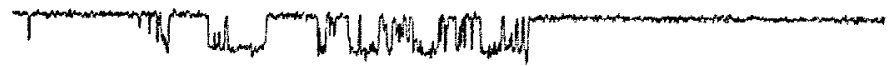

CHO Cell $\left(\alpha_{1} \beta_{1}\right)$

b1) $5 \mu \mathrm{M}$ GABA

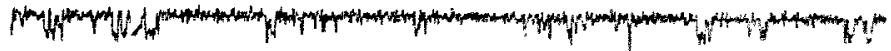

b2) $5 \mu \mathrm{MGABA}$

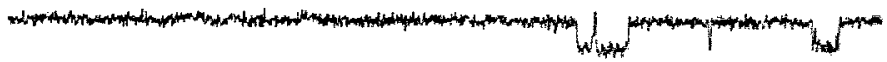

$\frac{50 \mathrm{~ms}}{2 \mathrm{set}}$

Fig. 8. Single channel $\mathrm{Cl}^{-}$currents were evoked by GABA in outside-cut patches from spinal cord neurones and al/ $\beta 1 \mathrm{CHO}$ cells. Patches were voltage clamped at $-75 \mathrm{mV}$. (a) In patches from spinal cord neurones, GABA (5 hM)-evoked channel openings were composed predominantly of the $27 \mathrm{pS}$ main conductance state. (b1) A typical response to GABA ( 3 in) in a patch irom an al, $/ \beta 1$ CHO cell. The openings were briefer than in spinal cord neurones, and the predominant conductance in these patches was 19 pS. (b2) An example of the $27 \mathrm{pS}$ conductance state obtained in a patch from an $\alpha / \beta 1 \mathrm{CHO}$ cell. Time and current calibration bars at the lower right apply throughout.

\subsubsection{Single channel recordings}

$\mathrm{GABA}_{\mathrm{A}}$ receptor channels resorded from mouse spinal cord neurones opened to a main conductance state of $27 \mathrm{pS}$, although occasional 19 and $11 \mathrm{pS}$ openings were recorded (Macdonald et al., 1989), and the channels opened in bursts of openings (fig. 8a). In contrast $\alpha 1 / \beta 1 \mathrm{GABA}_{\mathrm{A}}$ recuptor channels recorded from $\mathrm{CHO}$ cells opened to a main conductance state of $19 \mathrm{pS}(86 \mathrm{~s}$ of total current; fig 8b1) with few openings to the $11 \mathrm{pS}$ (4\% of total current) and $27 \mathrm{pS}(9 \%$ of total current) conductance states (fig. $8 \mathrm{~b} 2$ ). The channels opened singly and in relatively brief bursts (9313 openings recorded from 20 patches). Openings of the $\alpha 1 / \beta 1 \mathrm{GABA}_{\mathrm{A}}$ receptor channels were briefer than openings of mouse spinal cord

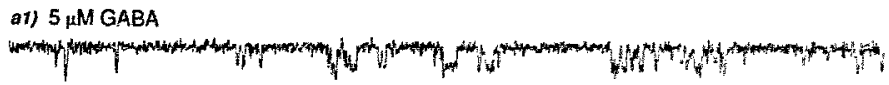

a2) $5 \mu \mathrm{M} \mathrm{GABA}+50 \mu M$ PENTOBARBITONE

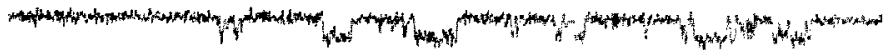

b1) $5 \mu \mathrm{MGABA}$

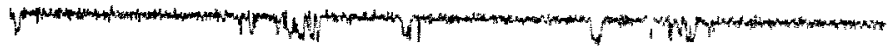

b2) $5 \mu \mathrm{M} \mathrm{GABA}+1 \mu \mathrm{M}$ PICROTOXIN

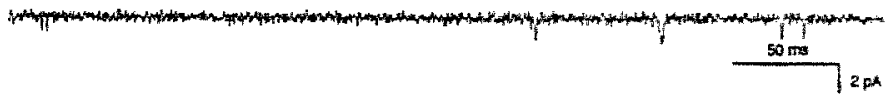

Fig, 9. Pentobarbitene and picrotoxin altered single channel chloride curtents evoked by GABA in outside-ont patches from $\alpha$ / $/ \beta 1$ CHO cels. (a 1 and b1) Responses to $5 \mu$ M GABA in two different patches betore the application of pentobarbitone or picrotoxin. respectively. GABA-evoked openings were predominentfy to the $19 \mathrm{pS}$ conductance state. ( $x 2$ ) In the presence of 50 iM pentobarbitone, the duration of the openings was prolonged. (b2) Picrotoxin (1 $\mu \mathrm{M}$ ) reduced both the frequency of channel opening and the duration of the openings. Tima and calibration bars at the lower right apply thisoughent. 
GABA $_{\mathrm{A}}$ receptor channels. Mean apparent open times of the $\alpha 1 / \beta 1$ and mouse spinal cord $G_{A B A}$ receptor channels (5 $\mu \mathrm{M}$ GABA) were 1.7 and 6.0 ms, respectively.

The $\alpha 1 / \beta 1 \mathrm{GABA}_{\mathrm{A}}$ receptor channel current was regulated by barbiturates and by picrotoxin (fig. 9), but was not enhanced by the benzodiazepine, diazepam (100 nM; not illustrated). Pentobarbitone $(50 \mu \mathrm{M})$ prolonged apparent mean open time to $2.8 \mathrm{~ms}$ (an increase of $67 \%$ ) (fig. 9a2). The increase in open time was accompanied by a decrease in apparent opening frequency from 12.3 to 6.1 openings per $s$ (5868 openings recorded from nine patches). In contrast, picrotoxin ( $1 \mu \mathrm{M}$ ) decreased apparent mean open time to $1.4 \mathrm{~ms}$ (a reduction of 19\%) and decreased apparent opening frequency to 2.2 openings per s (fig. $9 \mathrm{~b} 2 ; 592$ openings recorded from three patches).

\section{Discussion}

A stable cell line has been created carrying $\alpha$

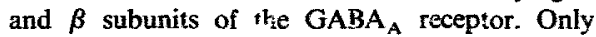
their transient expression has been achieved previously (lasting only 1 day), and an obstacle to deriving stable cell lines carrying this receptor has been identified here: when strong promoters were used with these cDNAs so that the receptors were continuously expressed at an initial high density, the cells did not survive, perhaps due to spontaneous activation of ionic fluxes. Only by the use of an inducible promoter and a low level of induced expression could a cell line carrying this receptor be maintained permanently.

The expressed receptors show the expected binding of muscimol and of TBPS. Their channels show the normal potentiation by a barbiturate and (at the ligand binding level, at least) by a steroid. They are likewise sensitive to bicuculline and picrotoxin.

Potentiation of the GABA-evoked response by benzodiazepines is either absent or too transient to measure in this system. This is to be expected, since it is now known that a $\gamma$ subunit is required to stabilize this response (Pritchett et al., 1989).

The number of binding sites per cell, in the range $100-300$, is low, as is expected from the known low efficiency of integration of steroid regulated DNAs. Nevertheless it is sufficient for electrophysiological analyses to be made. Further, in recent recloning of such cells this number has risen to about five times that level, which it adequate for binding studies. Calculation based upon the single channel conductance shows that the observed mean whole-cell current for the original population at saturating GABA concentration corresponds to about 300 receptor channels per cell, which is not less than the number estimated from the binding data (table 2); hence, many of the expressed membrane receptors are in the plasma membrane and form functional channels. We routinely observed that in order to produce similar size GABA responses on $\mathrm{CHO}$ cells compared to those induced on primary neurones, required approximately ten times more GABA. This apparent disparity in GABA concentration could be due to the exclusion of other essential subunits (e.g., $\gamma$, Pritchett et al., 1989) or more likely, refiects the smaller number of receptors expressed in $\mathrm{CHO}$ cells. A further contributory factor was the smaller mean conductance state (19sp) for GABA channels observed in CHO cells compared to $27-30 \mathrm{pS}$ observed as the most frequent conductance states in primary neurones.

The expressed receptors have some properties which are similar to those present on mouse spinal cord neurones. The expressed receptor channels were subject to allosteric regulations by barbiturates and picrotoxin. The expressed receptor channel openings were prolonged by pentobarbitone (Study and Barker, 1981; Macdonald et al., 1990; Twyman et al, 1989a,b) and shortened by picrotoxin (Twyman et al., 1989a). However, the expressed receptor channel current was not increased by benzodiazepines (Pritchett et al., 1988). These results are consistent with the observation that barbiturate and picrotoxin regulatory sites are present on $\alpha$ and $\beta$ subunits but that the $\gamma$ subunit is required for full expression of benzodiazepine sensitivity (Pritchett et al., 1989).

The single channel properties of the expressed channels were similar to those of mouse spinal cord neurones in the openings of 12,19 and $27 \mathrm{pS}$ channels which were recorded (Bormann et al, 1987; Macdonald et al., 1989). However, the ex- 
pressed channels differed substantiaily in the relatwe proportion of openings recorded. In receptors from spina cord neurones, the main conductance state was the $27-30 \mathrm{pS}$ state while in the expressed receptors the predominant state was a "subconductance state', the $19 \mathrm{pS}$ state. This observation might suggest the possibility that the main state is dependent on the presence of all subunits and that the different subconductance states may $b=$ due to the presence of receptors composed of a subset of subunits; however, when the same $\alpha 1$ and $\beta 1$ subunits were previously incorporated into the Xenopus oocyte (Levitan et al., 1988b), both in the $18 \mathrm{pS}$ and $28 \mathrm{pS}$ states occursed quite frequently. This could reflect differences in the two expressions systems used, but other criteria, including the pharmacology, appears very similar between $\mathrm{GABA}_{\mathrm{A}}$ receptors comprising $\alpha 1$ and $\beta 1$ subunis expressed in Xenopus oocytes and CHO cells. A further possibility is that the expressed GABA receptor may exhibit a time-dependent kinetic heterogeneity, allowing the channel to adopt various different conductance states at different times. This phenomenon has recently been reported for a 'native' GABA-operated ion channel in sympathetic neurones (Newland $\epsilon^{\dagger}$ al., unpublished).

The methodology used he. can now be used to create cell lines stably expressing various combinations of the subtypes of GABA ${ }_{A}$ receptor subunits (unpublished results). The only comparabie muitisubunit receptor cell line hitherto known is that of the Torpedo ACh receptor (Claudio et al., 1987) which was constructed in a fibroblast line, but its long-term stability has not been described. Such stable receptor-bearing lines offer a new resource for pharmacology and electrophysiolosy. Their reproducibility, accessibility and the ease of patch-clamping are some of the obvious tec:inical advantages. Drug screening with various linant types (GABA mimeties, benzodiazepines, sterc is, etc.) could be readily automated using such cultured cells. Single channel analyses are facilitated by the homogeneous population. However, the greatest benefit of this type of cell line will be, we believe, the ability to isolate the effects due to particular subunits or subtypes of the receptor and to analyze their relationships to the single channel parameters (e.g. subconductance states, desensiti- sation rates, gating kinetics, etc.). Mutagenesis of sites related to ligand binding and to channel function will acquire a new dimension when it becomes applied to such subtype-specific permanent reservoirs of receptors.

\section{Acknowledgements}

The authors wish to thank Drs. Roy Twyman sand Carl Rogers for their help with the single channel analysis and Timothy P. Angeloti and Dr. Michael Uhler for helpful dis. cussion and maintenance of CHO cells. This work was supported by USPHS and Lucille P. Matkey Foundation grants to R.LM. and a NRSA postdoctoral fellowhip to N.P.

\section{References}

Garnard. EA. 198\%. The structure of the GABA/ benzodiazepine receptor comptex with is gated ion chanrat. in: GAB.4 and Benzodiazepine Receptors. Volume II. ad. R.F. Squires (CRC Press, Iec. Boca Raton, FL) p. 103.

Blair. L.A.C. E.S. Levian. J. Marshanl, V.E. Dionne and E.A. Bamard. 1988, Single subunits of the GABA, receptor frrm ion channels with properties of the natiwe receptor. Science 242, 577 .

Boman, J., O.P. Hammill and B. Sakman. 1987, Mechanism of anion perneation through channels gated by glycine and $\gamma$-aminobudyric acid in mouse cultured spinal nemront. $J$. Physiol. 385. 245.

Casaloti, S.O. F.A. Stepluenson and E.A. Barnard, 9886, Separate subuits for grgentst and benzodizzapine binding in the $\gamma$-aminobuxylit acid, receptot oligomer, 3 . Biot. Chern. $261,15013$.

Chen, CA and H. Okayama. 1987, High-efficiency transtormation of mammatian cells by plasmid DNA. Mol. Cell. Biol. 7, 2745 .

Chirgwin. J.M. A.E. Przybyla. R.J. MacDonald and W.J. Rutter, 1979. Isolation of biologically acive ribonucleic acid from sources entiched in ribonuclease. Biochemistry 18,5294 .

Caudio. T.L. W.N. Green. D.S. Harman. D. Hayden. H.L. Paulson. F.I. Sigworth, S.M. Sine and A. Swedlund. 1987, Genetic reconstruction of functional aceylcholine receptor channels in mouse fibroblasts. Science 238, 1688.

Feinberg. A.F, and B. Vogelstein 1983, A technicue for tadio labeling Diva restriction endonuclese fragmexts to high specific activity Anal. Biochen. 132.6.

Gormen. C., 1985. High efficiency gene transfer intw manmatian celis. in: Cloning A Rractical Approach, Vol. II. ed. D.M. Hover (iRL Press. Oxford) p. 143 .

Hamil, O.P. A. Marav, E. Neher, B. Sakmona and F.J. Siguorth. 1981. Improwed foldhwlawap techniques for high-resolution current reocording membrane patches. Pllugers Archin, 391,85 . 
Farrison, N.L. and M.A. Simmonds, 1984, Modulation of the GABA receptor complex by a steroid anaesthetic, Brain Res. 323, 287.

Levitan, ES., L.A.C. Blair, V.E. Dionne and E.A. Barnard 1988a, Biophysical and pharmacological properties of cloner $\mathrm{GABA}_{\mathrm{A}}$ receptor subunits expressed in Xenopus ocytes, Neuron 1, 773.

Levitan, E.S., P.R. Schofield, D.R. Burt, L.M. Rhee, W. Wisden, M. Kohler, N. Fujita, H.F. Rodriguez, A. Stephenson, M.G. Darlison, EA. Bamard and P.H. Seeburg, 1988b, Structural and functional basis for $\mathrm{GABA}_{\mathrm{A}}$ receptor heterogeneity. Nature 335, 76.

Macdonald, R.L., C.J. Rogers and R.E. Twymen, 1989, Kinetic properties of the $\mathrm{GABA}_{\mathrm{A}}$ receptor main conductance state of mouse spinal cord neurones in culture, J. Physiol. 410 , 479.

Macdonald, R.L., C.J. Rogers and R.E. Twyman, 1990, Barbiturate regulation of kinetic properties of the GABA receptor channel of mouse spinal cord neurones in culture, J. Physiol., in press.

Mamalaki, C., F.A. Stephenson and E.A. Barnard, 1987, The $\mathrm{GABA}_{\mathrm{A}}$ /benzodiazepine receptor is a heterotetramer of homologous a and $\beta$ subunits, EMBO J. 6, 561 .

Maniatis, T., E.F., Fritsch and J. Sanbrook, 1982, Molecular Cloning: A Laboratory Manual (Cold Spring Harbor Laboratory, Cold Spring Harbor, N.Y.).

McManus, O.B., A.L. Blatz and K.L. Magleby, 1987. Sampling $\log$ binding fitting and plotting durations of open and shut intervals from single channels and the effects of noise. Pflugers Archiv. 410, 530.

Peters, J.A., E.F. Kirkness, H. Callachan, J.3. Lambert and A.J. Turner, 1988, Modulation of the GABA $_{A}$ receptor by depressant barbiturates and preznane steroids, $\mathrm{Br}, \mathrm{J}$. Pharmacol. 14, 1257.

Pritchett, D.E., H. Sontheimer, C.M. Gorman, H. Kettenmann, P.H. Seeburg and P.R. Schofield, 1988, Transient expression shows ligand gating and allosteric potentiation of GABA $_{A_{A}}$ receptor subunits, Science 242, 1306.
Pritchett, D.B., H. Sontheimer, B.D. Shivers, S. Ymer, H. Kettenmann, P.R. Schofield and P.H. Seeburg, 1989, Importance of a novel $\mathbf{G A B A _ { A }}$ receptor stbunit for benzodiazepine pharmacology, Nature 338, 582.

Schofield, P.R., MG. Daritson, N. Fujita, D.R. Burt, F.A. Stephenson, H. Rodriguez, L.M. Rhee, J. Ramachandran, V. Reale, T.A. Glencorse, P.H. Seeburg and E.A. Barnard, 1987, Sequence and functional expression of the GABA receptor shows a ligand-gated receptor super-family, $\mathrm{Na}$ ture 328, 221.

Sigel, E. and E.A. Bamard, 1984, A y-aminobutyric acid/ benzodiazepine receptor complex from bovine cerebral cortex, J. Biol. Chem. 259, 7219.

Smart, T.G., 1987. Single calcium-activated potassim channels recorded from cultured rat sympetietic neurones, $J$. Physio. 389, 337.

Stephenson, F.A., M.J. Duggan and S.O. Casalott, 1989, Idt:ntification of the a3-subunit in the GABA receptor purified from bovine brain, FEES Lett. 243, 358.

Study, R.E. and J.L. Barker, 1981, Diazepam and (-)-pentobarbital: fluctuation analysis reveals different mechanisms for potentiation of $\gamma$-aminobutyric acid responses in cujtured central neurones, Proc. Natl. Acad. Sci. U,S.A. 178, 7180.

Treisman, R., 1987, Identification and purification of a polypeptide that binds to the $\mathrm{c}$-fos serum responsa element, EMBO J. 6. 2711.

Twyman, R.E., C.J. Rogers and R.L. Macdonald, 1989a, Pentobarbital and picrotoxin have reciprocal actions on singie GABA , receptor channels, Neurosci. Lett. 96, 89.

Twyman, R.E., C.J. Rogers and R.L. Macdonald, 1989b, Differential reguiation of $\gamma$-aminobutyric acid receptor channels by diazepam and phenobartital, Neurology 25, 213.

Zinn, K., D. DiMaio and T. Maniatis, 1983, Identification of two distinct regulatory regions adjacent to the human $\beta$-interferon gene, Cell 34,865 . 